\title{
The Impact of Corporate Social Responsibility on Customer Satisfaction and Customer Perceived Value
}

\author{
Haoli Shi ${ }^{1, a}$ \\ School of Business Administration, Southwestern University of Finance and Economics, Chengdu, Sichuan, 611130, \\ China \\ Corresponding author's e-mail: angela@cas-harbour.org
}

\begin{abstract}
CSR, short for corporate social responsibility, is a key issue both for companies and all stakeholders. Many companies invest a lot in CSR in order to obtain new customers attracted by identification of its values and missions. In turn, customers need a brand with good image and reputation to show who they are. The purpose of this study are to analyze how CSR impact customer satisfaction, how customer perceived value, and whether Chinese customers feel more satisfied with the domestic companies with well performed CSR than those companies without that. The relevant data in this paper are collected from questionnaire and are employed to text hypotheses about CSR through SPSS. And the results show that Chinese customers' satisfaction and perceived value can be enhanced by the well performed CSR of the domestic companies.
\end{abstract}

Keywords: CSR, Customer Satisfaction, Customer Perceived Value, Domestic Companies

\section{INTRODUCTION}

Being ethical and performing well of all aspects of corporate social responsibility (CSR) is critical for a company to succeed and dominate in today's competitive market. In 2012, more than $90 \%$ of Fortune 500 companies had CSR expenses, and the total charitable donations of the largest 100 companies were 610 million dollars[1]. There are many existing articles that explore by being ethical how companies can increase customer satisfaction and loyalty, but domestic and foreign companies may have different impact on customer satisfaction in the mind of Chinese customers by being ethical. The aim of the study is to explore whether there is a difference in customer perceived value and customer satisfaction of domestic and foreign companies by being ethical. The objective is to deepen the understanding of how domestic and foreign companies CSR actions influence customer perceived value and customer satisfaction in China.

\section{LITERATURE REVIEW}

\subsection{Corporate Social Responsibility (CSR)}

CSR is defined as a commitment of companies to reducing all harmful effects and maximizing wealth and its long-run beneficial impact on society or community[5]. Widely accepted definition of about CSR is stating "the social responsibility of business encompasses the economic, legal, ethical, and discretionary (philanthropic) expectations that society has of organizations." [2]. In order to simplify the study, we use responsibilities to employees, responsibilities to customers, environmental responsibilities and philanthropic responsibilities as four key dimensions of CSR in the context of Chinese market.

\subsection{Customer Satisfaction and Effect of CSR}

Customer satisfactions are feelings of person in term of pleasure that shows expectations of the product/Services to their expectations[6]. CSR positively influences customer satisfaction by leaving a good impression in the mind of customers.

H1: CSR positively affects customer satisfaction.

\subsection{Customers Feel More Satisfied about Domestic Companies Performing CSR Well}

Many articles and surveys have compared the Chinese customers Satisfaction about foreign and domestic companies CSR performance, and the results show that most of them feel less satisfied about domestic company's performance. However, customers value domestic CSR performance, therefore we propose these hypotheses as follows.

H2: Customers feel more satisfied about domestic company's good CSR performance.

H2a: Customers feel more satisfied about domestic company's responsibilities to employees.

H2b: Customers feel more satisfied about domestic company's responsibilities to customers.

H2c: Customers feel more satisfied about domestic company's environmental responsibilities.

H2d: Customers feel more satisfied about domestic company's philanthropic responsibilities. 


\subsection{Customer Perceived Value and Effect of CSR}

Customer perceived value is defined as a comprehensive evaluation made by a customer based on the perception given by the company and the perception of the practicability of a certain product or service[7]. Customers are driven by value to use a specific product or service. Many empirical research results also show that customer perceived value and satisfaction are indeed related, and the former can predict the latter to a certain extent.

H3: CSR positively affects customer perceived value.

H4: Domestic company's CSR performance positively affects customer perceived value of Chinese customers more.

H4a: Domestic company's responsibilities to employees positively affects customer perceived value of Chinese customers more.

H4b: Domestic company's responsibilities to customers positively affects customer perceived value of Chinese customers more.

H4c: Domestic company's environmental responsibilities positively affects customer perceived value of Chinese customers more.

H4d: Domestic company's philanthropic responsibilities e positively affects customer perceived value of Chinese customers more.

\section{DESIGN OF THE SURVEY}

\subsection{Sample and Data Collections}

In order to test the hypothesis above, the study conducted a survey from 162 sample people and the sample and survey procedures are listed below.

\subsection{Sample}

We used convenience technique to collect data and wenjuanxing to design, distribute and collect questionnaire.
Among all the respondents, $37.65 \%$ are male and $62.35 \%$ are female. $87.66 \%$ of them have bachelor or above degree. $51.85 \%$ of them are $18-25$ years old, $14.81 \%$ are $26-30$ years old, and $22.84 \%$ are between $31-40$ years old. The questionnaire was written in Chinese, and the SPSS was used to get the results.

\subsection{Measures}

The questionnaire was design into three sections. Section A was based on the CSR questions in four dimensions mentioned above, how these impacted customer satisfaction and whether they feel more satisfied when domestic companies had good CSR performance. Section B was based on CSR questions, how these impacted customer perceived value and whether they feel more satisfied about the perceived value when domestic companies had good CSR performance. All variables were measured using a five-point Likert-type response scale started from strongly Agree (5), Agree (4), Neutral (3), Disagree (2) and strongly Disagree (1). Section C was personal basic information.

\subsection{Data Analysis Procedure}

For testing hypothesis above, the correlation was used to demonstrate the relationship between CSR, customer satisfaction, customer perceived value, and domestic companies CSR performance. The regression was also used to test the significance of the relationship.

\section{ANALYSIS OF THE RESULTS}

\subsection{Data Distribution}

Table 1 and table 2 are showing descriptive statistics between descriptive variables.

\section{Table 1 CSR \& Customer Satisfaction}

\begin{tabular}{|c|c|c|c|c|c|}
\hline & $\mathrm{N}$ & Min. & Max. & Mean & SD \\
\hline 3.1 PR positively to $\mathrm{CS}$ & 162 & 1 & 5 & 3.85 & 1.029 \\
\hline 3.2 ER positively to CS & 162 & 1 & 5 & 4.01 & 0.991 \\
\hline 3.3 Customer R positively to. CS & 162 & 1 & 5 & 4.13 & 0.913 \\
\hline 3.4 Employee R positively to. CS & 162 & 1 & 5 & 3.90 & 1.001 \\
\hline 3.5 Domestic CSR positively to CS more & 162 & 1 & 5 & 3.88 & 1.014 \\
\hline \multicolumn{6}{|c|}{ Table 2 CSR \& Customer Perceived Value } \\
\hline & $\mathrm{N}$ & Min. & Max. & Mean & $\mathrm{SD}$ \\
\hline 2.1 PR positively to $\mathrm{CPV}$ & 162 & 1 & 5 & 3.95 & 1.044 \\
\hline 2.2 ER positively to $\mathrm{CPV}$ & 162 & 1 & 5 & 4.06 & 0.937 \\
\hline
\end{tabular}




\begin{tabular}{llllll} 
2.3 Customer R positively to. CPV & 162 & 1 & 5 & 4.17 & 0.941 \\
2.4 Employee R positively to. CPV & 162 & 1 & 5 & 4.07 & 1.013 \\
2.5 Domestic CSR positively to CPV more & 162 & 1 & 5 & 3.87 & 0.960 \\
\hline
\end{tabular}

Table 1 shows minimum, maximum, mean and std. deviation of the relation how CSR impacts customer satisfaction. The mean of 2.1, 2.2, 2.3, 2.4, 2.5 are all greater than 3(neutral). And table 2 shows minimum, maximum, mean and std. deviation of the relation how CSR impacts customer perceived value. The mean of 3.1, 3.2, 3.3, 3.4, 3.5 are all greater than 3 (neutral).

\subsection{Correlation}

Table 3 and table 4 show relationship between descriptive statistics, bivariate correlations and estimates of reliability for all variables.

Table 3 Correlation of Domestic Companies CSR Performance \& Customer Perceived Value

\begin{tabular}{|c|c|c|c|c|c|c|c|}
\hline & M & SD & 2.1 & 2.2 & 2.3 & 2.4 & 2.5 \\
\hline 2.1 PR positively to $\mathrm{CPV}$ & 3.95 & 1.044 & 1 & & & & \\
\hline 2.2 ER positively to $\mathrm{CPV}$ & 4.06 & 0.937 & $0.562^{* *}$ & 1 & & & \\
\hline 2.3 Customer R positively to $\mathrm{CPV}$ & 4.17 & 0.941 & $0.590^{* *}$ & $0.594^{* *}$ & 1 & & \\
\hline 2.4 Employee R positively to $\mathrm{CPV}$ & 4.07 & 1.013 & $0.567^{* *}$ & $0.578^{* *}$ & $0.509^{* *}$ & 1 & \\
\hline 2.5 Domestic CSR positively to CPV more & 3.87 & 0.960 & $0.477^{* *}$ & $0.437^{* *}$ & $0.457^{* *}$ & $0.419^{* *}$ & 1 \\
\hline
\end{tabular}

*. Correlation is significant at the 0.05 level (2-tailed).

**. Correlation is significant at the 0.01 level (2-tailed).

Total sample size is $n=162$, alpha reliability of all variables is 0.843 (greater than 0.8 ).

The questionnaire dimension in the table is tested for reliability. The reliability value is greater than 0.8 , indicating that all items have internal consistency and high reliability. Philanthropic $\mathrm{R}$ positively to customer perceived $\mathrm{V}$ and domestic CSR positively to CPV more are at $(\mathrm{r}=0.477$ , when $\left.\mathrm{p}<0.01^{* *}\right), \mathrm{r}=0.477$ is showing strong positive relation between 2.1 and 2.5 on $\mathrm{P}$ value at $* *$ which is less than 0.01 . There is also a strong positive correlation between the Environmental $\mathrm{R}$ positively to customer perceived $\mathrm{V}$ and domestic CSR positively to CPV more $(\mathrm{r}=$ $0.437, \mathrm{P}<0.01 * *)$. There is also a strong positive correlation between the $\mathrm{R}$ to customers positively to customer perceived $\mathrm{V}$ and domestic CSR positively to CPV more $(\mathrm{r}=0.457, \mathrm{P}<0.01 * *)$. There is also a strong positive correlation between $\mathrm{R}$ to employees positively to customer perceived $\mathrm{V}$ and domestic CSR positively to CPV more $(\mathrm{r}=$ $0.419, \mathrm{P}<0.01 * *)$. All our hypothetical variables are correlated, which also shows the acceptance of the overall research model.

Table 4 Correlation of Domestic Companies CSR Performance \& Customer Satisfaction

\begin{tabular}{|c|c|c|c|c|c|c|c|}
\hline & $\mathrm{M}$ & SD & 3.1 & 3.2 & 3.3 & 3.4 & 3.5 \\
\hline 3.1 PR positively to $\mathrm{CS}$ & 3.85 & 1.029 & 1 & & & & \\
\hline 3.2 ER positively to $\mathrm{CS}$ & 4.01 & 0.991 & $0.605^{* *}$ & 1 & & & \\
\hline 3.3 Customer R positively to $\mathrm{CS}$ & 4.13 & 0.913 & $0.496^{* *}$ & $0.623^{* *}$ & 1 & & \\
\hline 3.4 Employee R positively to CS & 3.90 & 1.001 & $0.558^{* *}$ & $0.647^{* *}$ & $0.532^{* *}$ & 1 & \\
\hline 3.5 Domestic CSR positively to CS more & 3.88 & 1.014 & $0.613^{* *}$ & $0.515^{* *}$ & $0.554^{* *}$ & $0.544^{* *}$ & 1 \\
\hline
\end{tabular}

*. Correlation is significant at the 0.05 level (2-tailed).

**. Correlation is significant at the 0.01 level (2-tailed).

Total sample size is $n=162$, alpha reliability of all variables is 0.869 (greater than 0.8 ).

The questionnaire dimension in the table was tested for reliability. The reliability value is greater than 0.8 , indicating that all items have internal consistency and high reliability. Philanthropic R positively to customer $\mathrm{S}$ and domestic CSR positively to CS more are at $(r=0.613$, when $\left.\mathrm{p}<0.01^{* *}\right), \mathrm{r}=0.613$ is showing strong positive relation between 3.1 and 3.5 on $\mathrm{P}$ value at $* *$ which is less than 0.01 . There is also a strong positive correlation between the Environmental $\mathrm{R}$ positively to customer satisfaction and domestic CSR positively to CS more $(\mathrm{r}=0.515, \mathrm{P}<0.01 *$ $*)$. There is also a strong positive correlation between the $\mathrm{R}$ to customers positively to customer satisfaction and domestic CSR positively to CS more $(\mathrm{r}=0.554, \mathrm{P}<0.01 *$ *). There is also a strong positive correlation between $\mathrm{R}$ to employees positively to customer satisfaction and domestic CSR positively to CS more $(\mathrm{r}=0.544, \mathrm{P}<0.01 * *)$. All our hypothetical variables are correlated, which also shows the acceptance of the overall research model.

\subsection{Regression}

We used linear regression to test all hypotheses. We took the Domestic CSR positively to CPV more as the dependent variable, and the CSR positively to CPV as the independent 
variable. Our first hypothesis is that domestic companies Philanthropic $\mathrm{R}$ has a significant positive impact on the CPV more $\left(\beta=0.226^{*}, \mathrm{P}<0.05\right)$. There is no significant effect of domestic companies Environmental $\mathrm{R}$ on $\mathrm{CPV}$ more $(\beta=0.130, \mathrm{P}>0.05)$; there is a significant positive effect of domestic companies $\mathrm{R}$ to Customers on the $\mathrm{CPV}$ more $\left(\beta=0.185^{*}, \mathrm{P}<0.05\right)$; there is no significant effect of domestic companies $\mathrm{R}$ to Employees on the CPV more $(\beta=0.122, \mathrm{P}>0.05)$. Two of the four hypotheses are accepted, which proves that the impact of CSR positively to CPV has a positive impact on the domestic CSR positively to $\mathrm{CPV}$ more.

Table 5 Regression of Domestic Companies CSR Performance \& Customer Perceived Value

\begin{tabular}{lllll}
\hline & $\mathrm{B}$ & Sig & $\mathrm{R} 2$ & $\mathrm{R} 2$ \\
\hline 2.1 PR positively to CPV & $0.226^{*}$ & 0.015 & & 0.282 \\
2.2 ER positively to CPV & 0.130 & 0.161 & 0.300 & 0.043 \\
2.3 Customer R positively to CPV & $0.185^{*}$ & 0.171 & & \\
2.4 Employee R positively to CPV & 0.122 & 0.22 & \\
\hline
\end{tabular}

$* \mathrm{P}<0.05, * * \mathrm{P}<0.01, * * * \mathrm{P}<0.001$

We used linear regression to test all hypotheses. We took the Domestic CSR positively to CS more as the dependent variable, and the CSR positively to CS as the independent variable. Our first hypothesis is that domestic companies Philanthropic $\mathrm{R}$ has a significant positive impact on the CS more $(\beta=0.370 * * *, P<0.001)$. There is no significant effect of domestic companies Environmental R on CS more $(\beta=0.007, P>0.05)$; there is a significant positive effect of domestic companies $\mathrm{R}$ to Customers on the CS more ( $\beta=$ $0.272 * * *, \mathrm{P}<0.001)$; there is a significant effect of domestic companies $R$ to Employees on the CS more ( $\beta=$ $0.178, \mathrm{P}<0.05)$. Three of the four hypotheses are accepted, which proves that the impact of CSR positively to CS has a positive impact on the domestic CSR positively to CS more.

Table 6 Regression of Domestic Companies CSR Performance \& Customer Satisfaction

\begin{tabular}{lllll}
\hline & B & Sig & R2 & R2 \\
\hline 3.1 PR positively to CS & $0.370 * * *$ & 0.000 & & \\
3.2 ER positively to CS & 0.007 & 0.940 & 0.478 & 0.646 \\
3.3 Customer R positively to CS & $0.272 * * *$ & 0.000 & & \\
3.4 Employee R positively to CS & $0.178^{*}$ & 0.029 & & \\
\hline
\end{tabular}

$* \mathrm{P}<0.05, * * \mathrm{P}<0.01, * * * \mathrm{P}<0.001$

\section{CONCLUSION}

The results mentioned above support H1 (CSR positively affects customer satisfaction). The study of Arslan Irshad, etc. (2017) [4], the study of Chung, K.-H. etc. (2015) [3] also support our hypothesis. H2 (Customers feel more satisfied about domestic company's good CSR performance) is also supported by the results, but $\mathrm{H} 2 \mathrm{c}$ is not supported by the results. The results also supported H3 (CSR positively affects customer perceived value), H4 (Domestic company's CSR performance positively affects customer perceived value of Chinese customers more), but do not support $\mathrm{H} 4 \mathrm{a}$ and $\mathrm{H} 4 \mathrm{c}$.

There are many limitations in the study. The main limitation is that due to the time and finance constraints, we used convenience sample, and the questionnaire was distributed and collected online exclusively. Most of the people in the sample were students aging from 18-25, therefore the results may not apply to other segments. The other limitation is that the hypotheses are not precise and the conceptual model is not comprehensive enough.

The future research may collect data from broader segments to prove or disprove hypotheses mentioned above, and may incorporate psychology theories in conceptual model to give a clearer definition and evaluation of customer satisfaction and customer perceived value.

\section{ACKNOWLEDGMENT}

This research was supported by many people. I would like to appreciate my tutors for giving me kind advices, which were very helpful. I am also grateful for my family and friends, who were active in helping me find enough participants in my survey.

\section{REFERENCES}

[1] Bai X, Chang J. (2015) Corporate social responsibility and firm performance: the mediating role of marketing competence and the moderating role of market environment. Asia Pacific Journal Management, 32:505-530.

[2] Carroll, A. B. (1979). A three-dimensional conceptual model of corporate performance. Academy of management review, 4(4), 497-505. 
[3] Chung, K.-H., Yu, J.-E., Choi, M.-G., \& Shin, J.-I. (2015). The effects of CSR on customer satisfaction and loyalty in China: the moderating role of corporate image. Journal of Economics, Business and Management, 3(5), 542- 547.

[4] Irshad, A., Rahim, A., Muhammad, F. K. \& Muhammad, M. K. (2017). The Impact of Corporate Social Responsibility on Customer Satisfaction and Customer Loyalty, Moderating Effect of Corporate Image (Evidence from Pakistan). City University Research Journal, 63-73.

[5] Mohr, L. A., Webb, D. J., \& Harris, K. E. (2001). Do consumers expect companies to be socially responsible? The impact of corporate social responsibility on buying behavior. Journal of Consumer affairs, 35(1), 45-72.

[6] Oliver, R. L. (1980). A cognitive model of the antecedents and consequences of satisfaction decisions. Journal of marketing research, 460-469.

[7] Zeithaml, V. A., Berry, L.L., \& Parasuraman (1996). The behavioral consequences of service quality. Journal of Marketing, 60. 